\title{
New Perspectives on Critical Marketing and Consumer Society
}


This page intentionally left blank 


\section{New Perspectives on Critical Marketing and Consumer Society}

Edited by

Elaine L. Ritch

Glasgow Caledonian University, UK

and

Julie McColl

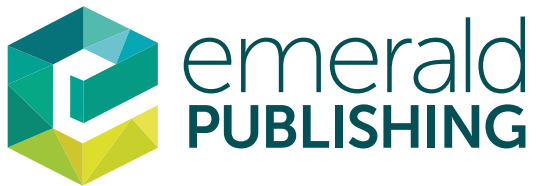

United Kingdom - North America

Japan - India - Malaysia - China 
Emerald Publishing Limited

Howard House, Wagon Lane, Bingley BD16 1WA, UK

First edition 2021

Copyright $\odot 2021$ Emerald Publishing Limited

\section{Reprints and permissions service}

Contact: permissions@emeraldinsight.com

No part of this book may be reproduced, stored in a retrieval system, transmitted in any form or by any means electronic, mechanical, photocopying, recording or otherwise without either the prior written permission of the publisher or a licence permitting restricted copying issued in the UK by The Copyright Licensing Agency and in the USA by The Copyright Clearance Center. Any opinions expressed in the chapters are those of the authors. Whilst Emerald makes every effort to ensure the quality and accuracy of its content, Emerald makes no representation implied or otherwise, as to the chapters' suitability and application and disclaims any warranties, express or implied, to their use.

\section{British Library Cataloguing in Publication Data}

A catalogue record for this book is available from the British Library

ISBN: 978-1-83909-557-3 (Print)

ISBN: 978-1-83909-554-2 (Online)

ISBN: 978-1-83909-556-6 (Epub) 


\section{Acknowledgments}

We would like to acknowledge our colleagues who contributed to this edited book with their insightful reflections and critical thinking around their topics of expertise.

We would also like to acknowledge the many interesting conversations that we have with our colleagues and students that enhanced and stimulated our own insight and reflection. 
This page intentionally left blank 


\section{Contents}

List of Tables $\quad$ xi

List of Figures xii

List of Images $\quad$ xiii

Abbreviations xv

Biographies xvii

CHAPTER 1: Introduction

Julie McColl and Elaine L. Ritch

CHAPTER 2: Disruptive Innovation

Elaine L. Ritch and Julie McColl

CHAPTER 3: The Changing Landscape of Consumerism Advancing the SOR Framework of Stimuli that Encourages Impulsive Online Consumption

Fiona Keegan, Elaine L. Ritch and Noreen Siddiqui

CHAPTER 4: Customer-Company Relationships: The Key Dimensions and Leveraging Social Media to Build Relationships

Nilay Balkan

CHAPTER 5: The Evolution of Big Data in Marketing:

Trust, Security and Data Ownership

Julie McColl and Elaine L. Ritch

CHAPTER 6: Social Media, Social Comment and the Moralising Media-Scape

Lindsey Drylie Carey, Mary Irwin and Jennifer Anne Yule 
THEME 2: Pseudo Modernity and Co-creation of Experiences

CHAPTER 7: Pseudo Modernity

Elaine L. Ritch and Julie McColl

CHAPTER 8: The Customer Engagement Journey:

Establishing Propositions

Cara Connell, Ruth Marciniak and Lindsey Drylie Carey

CHAPTER 9: The Use of Retail Spaces as Examples of Disruption Innovation

Ruth Marciniak

CHAPTER 10: Social Shopping: Implications for Store Retailing

Noreen Siddiqui

CHAPTER 11: Experiencing the Experience Economy Jenny Flinn

\section{THEME 3: Evolutionary Societies and 'Woke'}

Branding

CHAPTER 12: Brand Purpose and 'Woke' Branding Campaigns

Julie McColl, Elaine L. Ritch and Jennifer Hamilton

CHAPTER 13: Woke Awareness for Sustainability

Elaine L. Ritch and Julie McColl

CHAPTER 14: The 'Race to the Bottom': Moving Closer to Home?

Elaine L. Ritch and Julie McColl

CHAPTER 15: Inclusive Identities: Challenging Socially Constructed Perceptions of Femininity, Masculinity and Sexuality in Marketing

Elaine L. Ritch and Christopher A. Dodd 
CHAPTER 16: A Platform for Empowerment: Social Media and the Social Diffusion of the \#MeToo Movement

Stephanie Nicholson, Julie McColl and Elaine L. Ritch

CHAPTER 17: Concluding Comments and Future Directions Post Covid-19

Elaine L. Ritch and Julie McColl

Index 
This page intentionally left blank 


\section{List of Tables}

$\begin{array}{lll}\text { Table 3.1 Impulse Buying Frequencies } & 29\end{array}$

$\begin{array}{lll}\text { Table 3.2 } & \text { Fashion Involvement } & 29\end{array}$

Table 3.3 Emotions Experienced When Purchasing Fashion Online 30

$\begin{array}{lll}\text { Table 3.4 Online Environmental Stimulus } & 31\end{array}$

Table 3.5 Online Marketing Stimulus and Impulse Purchasing of Fashion 32

Table 4.1 Definition of the Customer Variables Relationship Marketing 41

Table 4.2 Social Media Characteristics Supported by Relationship Dimension and Relationship Marketing $\quad 47$

Table 8.1 Tenets of CE From a Consumer Behaviour and Relationship

Marketing Theoretical Perspective

$\begin{array}{lll}\text { Table 9.1 Lefebvre's Spatial Triad } & 104\end{array}$

Table 9.2 Lefebvre's (1991) Spatial Triad Applied to Retail Space 105

Table 13.1 The Two Cognitive Choice Systems 161 


\section{List of Figures}

Fig. 3.1 Stimulus-Organism-Response Framework 26

Fig. 3.2 Revised Stimulus-Organism-Response Framework 33

Fig. 7.1 The Key Characteristics of Postmodernity 80

Fig. 7.2 The Key Characteristics of Pseudo-Modernity 85

Fig. 8.1 The CE Journey 95

Fig. 9.1 The Misguided Sofa: Capitalising on Shoppers

$\begin{array}{ll}\text { Fig. 9.2 } & \begin{array}{l}\text { Misguided Designing Retail Space to Respond to } \\ \text { Shoppers' Needs }\end{array}\end{array}$

$\begin{array}{lll}\text { Fig. 9.3 } & \text { Misguided Purposely Designed Retail Space to Encourage } \\ & \text { Selfie Taking } & 108\end{array}$

$\begin{array}{lll}\text { Fig. 10.1 Use of Social Media by Generational Cohorts } & 117\end{array}$

$\begin{array}{lll}\text { Fig. 10.2 Fashion Consumer segments } & 119\end{array}$

Fig. 10.3 Social Shopping for Fashion Consumers within Retail Stores 121

Fig. 11.1 The Progression of Economic Value 130

$\begin{array}{lll}\text { Fig. 11.2 The Four Realms of Experience } & 135\end{array}$

$\begin{array}{lll}\text { Fig. 13.1 Sustainability Framework } & 156\end{array}$

Fig. 13.2 Planetary Resources are Finite 157

Fig. 13.3 China's Middle Class as per cent of Urban Households 158

$\begin{array}{lll}\text { Fig. 13.4 Sustainability Discourse } & 159\end{array}$

$\begin{array}{lll}\text { Fig. 13.5 Nudge Theory } & 160\end{array}$

$\begin{array}{lll}\text { Fig. 14.1 Cognitive Dissonance } & 174\end{array}$

Fig. 14.2 The Self-perpetrating Cycle Capturing the Race to the Bottom 178

$\begin{array}{lll}\text { Fig. 16.1 The Diffusion of Innovations } & 201\end{array}$ 


\section{List of Images}

Image 2.1 The Berlin Campaign that Did Not Welcome Google to the City 15

Image 2.2 Lena Library in Amsterdam, Where You Can Borrow Clothes 17

Image 2.3 Designer Creating Clothes that Grow with the Kid from 9 Months to 4 Years 18

Image 5.1 The Four Vs of Big data 57

Image 7.1 Postmodern Example of Art - Tracey Emin 'My Bed' $1998 \quad 77$

Image 7.2 Postmodern Example of Art - 'Fountain' by Marcel Duchamp 78

Image 7.3 Examples of Postmodern Business Models Innocent Drinks and $\begin{array}{ll}\text { Fruit Towers } & 79\end{array}$

Image 11.1 Cereal Killer Café, Camden 132

Image 11. 2 House of Vans Presents A Day to Remember 137

Image 11. 3 Paper to Print An Exhibition by Sean Cliver and Todd Bratrud - House of Vans 138

$\begin{array}{lll}\text { Image 13.1 Fly Urinal } & 163\end{array}$

Image 13.2 Encouraging Disposing Litter and Recycling 164

Image 13.3 Encouraging Using the Stairs: Tokyu Hands Shibuya 164

Image 13.4 Glasgow Caledonian University 'Nudge' to Encourage Students to Use the Hand Dryer Rather than Toilet Paper to Dry Their Hands 165

Image 13.5 ECOALF - Turning Ocean Waste into Clothing 166

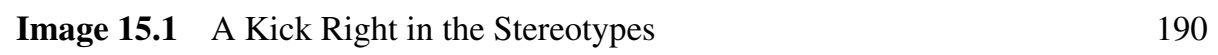

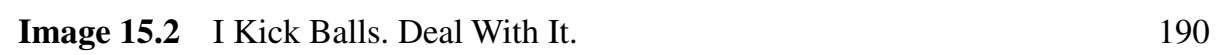

$\begin{array}{lll}\text { Image 15.3 Pharrell Williams Adidas Campaign } & 191\end{array}$

Image 17.1 'You Can Still Dunk In The Dark' 214

$\begin{array}{lll}\text { Image 17.2 Isolation Life } & 215\end{array}$ 
This page intentionally left blank 


\section{Abbreviations}

$\mathrm{CE}$ - Customer Engagement

CSR - Corporate Social Responsibility

DSP - Dominant Social Paradigm

MNO - Multi-national Organisation

NEP - New Environmental Paradigm

NGO - Non-government Organisation

SOR - Stimulus-Organism-Response Framework

USP - Unique Selling Proposition 
This page intentionally left blank 


\section{Biographies}

Nilay Balkan was awarded her $\mathrm{PhD}$ in 2020, in which she investigated the social media usage of micro businesses in building relationships and communities and the impact of this on social media engagement. She is currently a Lecturer in Marketing and Course Leader for 'Marketing Campaign Development and Research Tactics' and 'Marketing Management'. Her research interests include branding, strategic marketing, entrepreneurship and marketing in SMEs.

Cara Connell is a Lecturer in Fashion Marketing Communication and a Programme Leader for BA (Hons) International Fashion Branding at Glasgow Caledonian University. Her current research interests include customer engagement and marketing communication specifically within the fashion and luxury sectors.

Christopher A. Dodd, PhD CPsychol AFBPsS, is a Consumer Psychologist with a particular interest in the social, psychological and experiential aspects of consumption, whose research and teaching are informed by a focus upon people and their relationships within social and physical environments. He is a Chartered Psychologist and Associate Fellow of the British Psychological Society.

Lindsey Drylie Carey is a Senior Lecturer in Marketing and Research Methods from Glasgow Caledonian University. Her research interests cover the area of sustainability in the context of creative industries. She has published in the areas of communication, educational development and intercultural competence, and commented on consumer issues within the national and international press. She most recently contributed to the book Understanding Luxury Fashion, published by Palgrave Macmillan in 2020.

Jenny Flinn is a Lecturer in Events Marketing at the University of the West of Scotland. She is an experienced academic having worked in events management education for over 15 years leading programmes at undergraduate and postgraduate levels. Her research interests lie in the experiential aspect of events and festivals.

Jennifer Hamilton completed a BA (Hons) in Criminology while contributing to the 'Woke Branding' research in 2019. She is now working with primary care networks to promote the use of business analytics within healthcare settings to improve the provision of care.

Mary Irwin was most recently Senior Lecturer in Media and Communication at Northumbria University Newcastle and is currently Honorary Research Fellow in Media and Communication at Queen Margaret University, Edinburgh. She has published extensively in the fields of TV Studies and Cultural Studies. She is currently writing a monograph on TV Romantic Comedy Love Wars: TV Romantic Comedy (Bloomsbury, 2022) and is co-editing a collection on British TV comedy This Country: British Screen Comedy Cultures (Palgrave, 2021). 
Fiona Keegan is an experienced marketer and two times graduate of Glasgow Caledonian University. She has a passion for understanding consumer behaviour, which has been demonstrated in both her private and public sector works. She resides in Glasgow with her husband, four children and their dog, and her main hobby is interior design.

Ruth Marciniak is a Senior Lecturer and Senior Teaching Fellow in the British School of Fashion at Glasgow Caledonian University (GCU), with expertise in the field of fashion, branding, digital marketing and retailing. Based at GCU London, she is the Programme Leader for MSc Fashion and Lifestyle Marketing.

Julie McColl is an academic working across a number of universities in the UK. She has worked in the higher education sector for over twenty years and has held positions as Deputy Dean at York Business School and Assistant Head of Department at Glasgow Caledonian University.

Stephanie Nicholson graduated from Glasgow Caledonian University in 2019 with a BA(Hons) in International Marketing. Her dissertation investigated the impact of modern social movements, focussing on \#MeToo - a topic she is passionate about. After graduating, she completed a marketing internship with a global organisation, she currently works as a Marketing Executive for a marketing agency in Glasgow.

Elaine L. Ritch is a Senior Lecturer in Marketing and Programme Leader for the International Marketing UG programme at Glasgow Caledonian University. Her research focuses on fashion, retailing, consumer behaviours, consumer culture, and sustainability practices, from industry perspectives to consumer practice. Elaine leads on two modules: New Perspectives in Critical Marketing and Consumer Society (level 4) and Marketing, Design and Creativity (level 1) and has a Higher Education Fellowship.

Noreen Siddiqui is a Senior Lecturer in the Department of Fashion, Marketing Tourism and Events located within the Glasgow School for Business and Society at Glasgow Caledonian University, with expertise within digital marketing and retailing. Her $\mathrm{PhD}$ was in the development of Internet retailing by High Street fashion retailers. She is currently the Programme Leader for MSc Marketing and supervises PhD students in the area of digital marketing communications.

Jennifer Anne Yule is a Lecturer in Marketing at the University of Edinburgh. Prior to this position, she was a Faculty in the Marketing Department at Northeastern University in Boston and the University of Stirling. She has published widely in the field of social marketing with specific interests in health and wellbeing and food. 


\title{
Chapter 1
}

\section{Introduction}

\author{
Julie McColl and Elaine L. Ritch
}

\section{Introduction}

Social, technological and digital change over the last decade has accelerated rapidly, bringing about many corresponding changes in marketing strategies and tactics. These developments have instigated changes in consumer behaviour and expectations, and new business models have entered into the marketplace causing disruption to traditional modes of operation. This book seeks to examine and capture this change to offer a better understanding of the role of marketing in current society.

The book is designed for both undergraduate and postgraduate marketing students and will cover three main themes that currently dominate the marketplace: Disruption and the digital landscape; pseudo modernity and the co-creation of society; evolutionary lifestyles and 'woke branding'. Each theme is represented by relevant chapters which explore related areas using traditional and new theories and concepts applying these to markets and consumer changes and developments.

\section{Theme 1: Disruption and the Digital Landscape}

The first theme of the book is that of disruption and the digital landscape. The chapters included within this theme seek to explore disruptive innovation as it pertains to recent developments in the use of technology in consumer markets. Disruptive innovation is thought to be the most influential business idea of the twenty-first century, and although disruption to existing markets is not new, recent developments in technology have allowed companies to innovate using technology, without the need for a product or manufacturing base, providing services that seek to connect customers and companies and offer greater choice and convenience from a single platform. New technology has blurred the boundaries of consumption and production and has allowed communities greater power in the consumer/market relationship. This power evolves from the evolution of two-way communication which facilitates immediate customer feedback, positive and negative, that can influence the direction of sales and quickly improve or damage reputations. It also, however, allows for a more immediate response from companies in the management of customer relationships. Never before has society been so connected and have companies been so answerable for their actions. Digital technology and social media have facilitated developments in the representation of consumers, 
products and services and have allowed any individual to represent themselves as experts across markets offering advice and solutions for almost any given situation. For companies, digital technology and big data have given them access to minute-byminute information on purchases, hovers, clicks and searches, allowing them to compare day-on-day and year-on-year data to micro-segment markets and target them with minute precision across platforms. The Internet of Things allows interaction between digital objects, which furthers the sophistication of data and provides further information on how consumers interact between and across technology-enabled products. The development of digital technology, however, has raised fears over data protection and cyber security and the evolution of big data has quickly overtaken the laws and regulations that had been put in place in the protection of personal information. The chapters in this theme seek to highlight the impact of disruption for the global business environment as well as in consumer markets and across communication channels and highlight areas for future research.

\section{Chapter 2: Disruptive Innovation}

The chapter on disruptive innovation examines the Dominant Social Paradigm of production and consumption to establish the ways in which digital technology has been disruptive in creating new business models. This includes business models such as Uber and Airbnb that fall under collaborative consumption and the sharing economy. The chapter begins by considering how the Dominant Social Paradigm has compromised sustainability and concludes on the ways in which disruptive business models respond to the New Environmental Paradigm.

Chapter 3: The Changing Landscape of Consumerism - Advancing the SOR Framework of Stimuli that Encourages Impulsive Online Consumption

Digital technology has provided an additional platform for consumption that has been embraced by consumers and has provided a lucrative expansion for retailers. Using the Stimulus, Organism, Response Framework (SOR), this chapter examines the fashion consumer's online experience and the role that hedonism plays in encouraging consumption, particularly impulse consumption. This chapter examines how manipulated stimuli triggers impulsive fashion consumption, which can be used for fashion retailing and for encouraging alternative consumption that falls under the New Environmental Paradigm.

\section{Chapter 4: Customer-Company Relationships: The Key Dimensions and Leverag- ing Social Media to Build Relationships}

Social media gained prominence in academic literature because of its versatility for business purposes and the advantages it can provide businesses. One such advantage is social media's ability to develop the customer-company relationship. There are a number of factors that contribute to this development, starting with the accessibility afforded by social media. This chapter examines the various factors and social media characteristics that contribute to the development of customer-company relationships.

\section{Chapter 5: The Evolution of Big Data in Marketing: Trust, Security and Data Ownership}

The evolution of data-driven consumer society has brought with it greater fears over not just security of payment, but also security, and use and misuse of data. Algorithmic 
profiling is a sophisticated means of data collection, data that can be shared and may lead to targeting of vulnerable consumer groups and in some cases, discrimination. Using the Resource-Based View, this chapter explores the possibilities and market advantage offered to companies in the collection and efficient management of big data as well as the uses of profiling information in consumer markets. It also considers, from the consumer perspective, concerns over privacy, ethics and security of big data information.

\section{Chapter 6: Social Media, Social Comment and the Moralising Media-Scape}

This chapter is a theoretical contribution relating to the representation of society through social media. The premise of the chapter relates to the emergence of social media from the origins of the performance art of the 1970s and relating right back to the Theory of the Leisure Classes and Utilitarianism. The chapter reviews in particular the representation of food through social media and the proliferation of recipe information, celebrity chefs and food pictures as well as the explosion of wellness and related advice from non-experts in this area which is facilitated by social media.

\section{Theme 2: Pseudo Modernity and Co-creation of Experiences}

The second theme of the book focusses on pseudo modernity and the co-creation of experiences. In marketing terms, what has been termed modernist society is perceived to have been passive to marketing activity and advertising media which was communicated in a way that allowed little opportunity for interaction and feedback. The evolution of television and other forms of media in the 1950s and 1960s had extended the application of marketing to consumer society. Gradual changes in society influenced by the changing culture, music and art in the 1960s and 1970s led the way in the evolution of a more open and culturally fragmented postmodern society. The evolution of postmodernism acknowledged developments in media, art and architecture and particularly the advent of new technologies that challenged traditional methods of communication and customer experiences, acknowledging new realities that could not have been conceived of by previous generations with the creation of almost dream-like and unreal experiences, enhanced by the use of technology. The phases of modernity, postmodernity and the more recently proposed pseudo modernity, overlap and there is no clear period in time where there was a change from one to another; however, although criticised, such theorising helps to make sense of the progress of society and the technologies that support that progress. Kirby proposes that pseudo modern products are those that cannot and do not exist unless the consumer intervenes and interacts with them through the adoption of new technology. Throughout this period, consumer expectations have changed, consumers increase the spend in the experience economy with raised expectations that experiences will be a part and parcel of consumption and that they will be co-creators of and immersed in the development of experiences. The ongoing discussion in this theme of the book, therefore, is centred around post- and pseudo modern society and the co-creation of experiences through engagement with the media, the online retail environment, retail space, social media as a medium for social shopping and the ever developing experience economy.

\section{Chapter 7: Pseudo Modernity}

This chapter explores and unpacks the concepts of modernity, postmodernity and pseudo modernity and further develops Kirby's assertions that postmodernity is 
obsolete further developing his framework with examples of how pseudo modernity is experienced in the media and marketplace. The chapter begins by charting the move between modernity and postmodernity offering examples of postmodernity in media channels and advertising and considering the consequences on society, particularly on the environment and market development. The chapter concludes by offering an analysis and conceptualisation of pseudo modernity which can be applied and tested in future research studies.

\section{Chapter 8: The Customer Engagement Journey: Establishing Propositions}

The growth of online retailing is highly competitive; engaging customers with transactional retail websites is important to increase traffic, consumption and loyalty. This chapter explores the theoretical foundations and establishes the concept of customer engagement. It explores the concept of the consumer engagement journey, acknowledging technological advancement and considering the multitude of omni-channel brand touchpoints through which consumer engagement can be established, grown and maintained. The chapter proposes a framework that captures the concepts that are relevant to the consumer engagement journey and concludes by offering avenues for future research.

\section{Chapter 9: The Use of Retail Spaces as Examples of Disruption Innovation}

The transformation of retailing over the last two decades has been phenomenal. Regardless of channel, critical to successful retailing is to provide the consumer with positive experiences that are memorable and engage the consumer in a personal way, whilst at the same time, provide economic value for the business. Retailers who will perform well in the future will be those who tap into the desires of consumers to be more than shoppers. Utilising Lefebvre's special triad, this chapter will explore both physical and virtual retail spaces to determine the provision of sensory, emotional and stimulating retail experiences in the fashion and lifestyle retail sector. In doing so, alternative approaches to the use of retail space are exposed.

\section{Chapter 10: Social Shopping: Implications for Store Retailing}

Consumption of social media networks has given rise to a participatory culture where consumers work together to produce more content and share information on products and services to make better purchase decisions. Social shopping, a hybrid of social networking and online retailing, has emerged as a new way of shopping. This has given rise to new shopping technologies that maximise the opportunity for sociality with known or new friends. This chapter explores the impact of social media networks and technologies on the development of social shopping within retailing.

\section{Chapter 11: Experiencing the Experience Economy}

This chapter examines the growing role of events and experiences as marketing tools. Drawing upon Pine and Gilmore's theory of the experience economy and drawing on Maslow's hierarchy of human needs, this chapter starts by outlining how the economic base of developed societies has evolved to reflect the needs and wants of consumers in a post-industrial world. The chapter then explores the concept of the experience before examining the ways in which marketers are increasingly using events and experiences as a way to engage consumers and build brand loyalty through the creation of symbolic meaning. 


\section{Theme 3: Evolutionary Societies and Woke Branding}

The past 10 years has seen considerable societal change, particularly in the areas of ethical consumption, concerns over sustainability, worker's rights and the treatment of workers in the supply chain, gender equality and recognition of LGBTQIA+ identities. These issues are reflected in business and marketing in many positive and negative ways. Younger consumers have grave concerns over the environment and are more likely that any other generation to seek out sustainable and ethically produced products. However, price deflation, particularly in the area of fashion, has seen an increase in demand for inexpensive 'fast fashion'. The production of fast fashion renders clothing disposable and leads to increased waste and higher levels of land fill in developed countries. In turn, production methods in this low-cost supply chain lead to poor pay and conditions. Companies respond to changing societies and the concerns of the consumer by involving themselves in 'woke branding' campaigns that the feel is appropriate to their target market. The chapters in this section explore the changes in society, the mediums through which these changes evolve and are diffused, and the response of businesses to societal discourse.

\section{Chapter 12: Brand Purpose and 'Woke' Branding Campaigns}

The concept of brand purpose or 'woke' branding is not new, and in theoretical terms it can find its roots in Goodyear's concept of brand policy, the evolution of corporate brand concepts and concepts of corporate social responsibility. Brand strategies have evolved from supporting worthy causes to bring these causes into the heart of their brand strategy. For some companies such as Benneton and Lush, the cause is a central part of their DNA. Other companies have adopted issues that they perceive to be current and of significance to their target market. This chapter looks at 'woke' branding campaigns and considers the impact of these on Generation Z.

\section{Chapter 13: Woke Awareness for Sustainability}

Societal concerns for sustainability are growing and millennials report feeling that climate change is the biggest threat to humanity. This chapter explores how young people are challenging governments and businesses over sustainability and how some brands are using concepts of sustainability to align with new values and develop 'wokeness' so that they might be perceived by target consumers to be aware of current social, environmental and political issues. The chapter presents the concept of 'Nudge Theory' as a means of creating awareness and changing behaviour proposing it as a business model suitable for sustainable marketing campaigns.

\section{Chapter 14: The 'Race to the Bottom': Moving Closer to Home?}

Allegations that the workers employed in producing the goods we purchase are exploited have been made for over two decades. This is in part due to outsourcing production to developing countries; however, more recently, workers in the UK are allegedly facing exploitation including long and unsociable hours, productivity monitoring and pay that falls below what is required to live on (the living wage). This has allowed for a global decrease in commodity pricing. This chapter will explore consumer perceptions of allegations of exploitation and pricing and how companies can create value that allows them to help progress society as well as improve profitability. 
Chapter 15: Inclusive Identities: Challenging Socially Constructed Perceptions of Femininity, Masculinity and Sexuality in Marketing

The past few years have seen a sea change in terms of the portrayal of the LGBTQIA+ community in the media. LGBTQIA+ identities are more represented in mainstream society; this chapter explores how brands and retailers reflect LGBTQIA+ identities. Framed within the four waves of feminism, with the fourth recent wave including LGBTQIA+ representation, the chapter explores the growing acceptance of diverse gender and sexuality.

Chapter 16: A Platform for Empowerment: Social Media and the Social Diffusion of the \#MeToo Movement

The impact of \#MeToo on the media world has provided a voice to women globally that propels gender equality to the fore of social discourse. The movement provides an illustration of how social media can provide a voice to those who feel vulnerable and that collectively society can progress inclusively. Using Rodger's (1995) Theory of Innovation Diffusion, this chapter explores the diffusion of the \#MeToo message and the feelings and perceptions of Generation $\mathrm{Z}$ in receiving the message and becoming involved in the movement through social media.

\section{Chapter 17: Concluding Comments and Future Directions Post Covid-19}

The final chapter concludes by drawing a thread through the chapters of the book and considering the possible impact of Covid-19 and the use of new technologies and social marketing methods utilised to deal with it. 
Theme 1

\section{Disruption and the Digital Landscape}


This page intentionally left blank 